\title{
COMPARISON OF PAVEMENT PERFORMANCE MODELS FOR URBAN ROAD MANAGEMENT SYSTEM
}

\author{
IGORIS KRAVCOVAS*, AUDRIUS VAITKUS, \\ RITA KLEIZIENE் \\ Dept of Roads, Vilnius Gediminas Technical University, \\ Vilnius, Lithuania
}

Received 18 March 2020; accepted 3 June 2020

\begin{abstract}
The key factors for effective pavement management system (PMS) are timely preservation and rehabilitation activities, which provide benefit in terms of drivers' safety, comfort, budget and impact on the environment. In order to reasonably plan the preservation and rehabilitation activities, the pavement performance models are used. The pavement performance models are usually based on damage and distress observations of rural roads, and can be applied to forecast the performance of urban roads. However, the adjustment of the parameters related to traffic volume, speed and load, climate conditions, and maintenance has to be made before adding them to PMS for urban roads. The main objective of this study is to identify the performance indicators and to suggest pavement condition establishment methodology of urban roads in Vilnius. To achieve the objective, the distresses (rut depth and cracks), bearing capacity, and international roughness index (IRI) were measured for fifteen urban roads in service within a two-year period. The distresses, rut depth and IRI were collected with the Road Surface Tester (RST) and bearing capacity of pavement structures were measured with a Falling Weight Deflectometer
\end{abstract}

\footnotetext{
* Corresponding author. E-mail: igoris.kravcovas@vgtu.lt

Igoris KRAVCOVAS (ORCID ID 0000-0001-5772-6054)

Audrius VAITKUS (ORCID ID 0000-0001-5103-9747)

Rita KLEIZIENE (ORCID ID 0000-0001-7478-3069)

Copyright (c) 2020 The Author(s). Published by RTU Press

This is an Open Access article distributed under the terms of the Creative Commons Attribution License (http://creativecommons.org/licenses/by/4.0/), which permits unrestricted use, distribution, and reproduction in any medium, provided the original author and source are credited.
} 
(FWD). The measured distresses were compared to the threshold values identified in the research. According to the measured data, the combined pavement condition indices using two methodologies were determined, as well as a global condition index for each road. The analysed roads were prioritized for maintenance and rehabilitation in respect to these criteria. Based on the research findings, the recommendations for further pavement condition monitoring and pavement performance model implementation to PMS were highlighted.

Keywords: bearing capacity, international roughness index, pavement condition index, pavement distress, pavement management system, pavement performance model.

\section{Introduction}

Preservation of existing roads and streets has become a major activity for all levels of government. Deteriorating urban roads and reduced funding are a major problem for the local governments. Therefore, funds designated for pavements must be used as effectively as possible. One of the main components in the decision-making process is pavement condition assessment (PCA). Implementing this strategy allows each part of the entire road network to be individually evaluated and assigned a number representing pavement condition. Commonly, the road network is segmented, then each segment is assessed. Based on the assessment results the need for maintenance and rehabilitation (M\&R) is determined for each section.

To be able to reliably tell the condition of pavement as a whole, a number of individual factors - pavement performance indicators (PPI) must be evaluated. Indicators can be structural or functional. Functional indicators incorporate traffic safety and quality of ride parameters, while structural indicators encompass pavement state in regard to distresses, bearing capacity and ability to sustain traffic loads (AASHTO, 1993). A list of these PPI may include roughness, rut depth, cracking, deflection, pavement condition, surface modulus, ride index etc. (Haas, Hudson, \& Falls, 2015). Huang (2004) has grouped most of the flexible pavement distresses according to their type as well as the association to load.

- Structural load associated: alligator or fatigue cracking, patch deterioration, potholes, pumping and water bleeding.

- Structural non-load associated: block cracking, joint reflection cracking, longitudinal and transverse cracking, swell, pumping and water bleeding.

- Functional load associated: polished aggregate, rutting, patch deterioration, potholes, pumping and water bleeding. 
- Functional non-load associated: bleeding, corrugation, depression, lane/shoulder drop-off or heave, lane/shoulder separation, ravelling and weathering, swell, pumping and water bleeding.

Each identified pavement distress could be assigned a severity level. Based on this level, a M\&R strategy is applied (e.g., low severity block cracking may be eliminated by a thin wearing course, in case of more serious cracking overlays recycling may be needed (Adlinge \& Gupta, 2013)). Based on (Lietuvos automobilių kelių direkcija, 2018; TKTI, 1994) all registered distresses on Lithuanian road pavements are usually assigned one of the 3-5 levels of severity (e.g., transverse cracks are considered low severity when they are less than $6 \mathrm{~mm}$ wide, medium - between $6 \mathrm{~mm}$ and $19 \mathrm{~mm}$, high - more than $19 \mathrm{~mm}$ wide). Pavements with high severity distresses are bound to be rehabilitated sooner as the distress might reach a certain critical threshold soon, when the road section in question will no longer meet safe operable conditions. The Ohio Department of Transportation (2006) uses double scale to determine a distress impact on pavement. The first scale is the usual severity level and the second one is the level of extent. Distress severity levels and threshold values both differ depending on the country, state, road category or class, maintenance level and other factors.

The easiest and most accessible method of pavement distress survey is visual inspection by qualified and subjective experts. On the other hand, this method requires a lot of manpower and finances; it is not very time effective and sometimes provides unreliable results (Ragnoli et al., 2018). In order to overcome these disadvantages, various automated devices are used. Some of them are used to determine a specific pavement characteristic or distress (such as falling weight deflectometer (FWD) or ground penetrating radar (GPR)), others are multifunctional and register a number of pavement characteristics (such as mobile laboratory RST-28 (Ziliute, Laurinavicius, \& Kleiziene, 2011) used in Lithuania or multifunctional measurement vehicle MESAS (Pinkofsky \& Jansen, 2018) used in Germany). There have been numerous studies on automatic cracking detection from pavement image data (Gavilán et al., 2011; Lovas, Kertész, Fi, \& Barsi, 2008; Wang, Gopalakrishnan, Smadi, \& Somani, 2018; Xu \& Huang, 2005) or pothole detection using pavement video data (Huidrom, Das, \& Sud, 2013; Koch \& Brilakis, 2011). All researchers conclude that implementing some of these techniques road administrations could avoid buying costly multifunctional vehicles and still be able to detect certain distress types on a road using just a vehicle with a camera.
Comparison

of Pavement

Performance

Models for Urban

Road Management System 
Usually pavement condition is characterised by a number of pavement distresses and other factors. The pavement condition index (PCI) is most commonly used. Shah, Jain, Tiwari, \& Jain (2013) conducted a study, in which the combined OPCI (Overall PCI) was evaluated by considering the effects of four main pavement performance indicators such as distresses, roughness, structural capacity and skid resistance for selected urban road sections of Noida city. They concluded that pavement structural strength is one of the crucial factors, influencing pavement performance, thus should be considered when deciding the maintenance and repair strategy for an urban road network. The Ohio Department of Transportation (2006) uses a Pavement Condition Rating (PCR) in a form of scale, which has a range from 0 to 100 , where 100 represents an ideal pavement with no notable distress, while 0 represents a pavement with all distress of the highest severity and extent. Baladi, Dawson, Musunuru, Prohaska, \& Thomas (2017) describe a balanced pavement condition rating system based on the remaining structural period (RSP) and remaining functional period (RFP). RFP can be considered a pavement rating for the users, whereas RSP is an agency rating. RFP is calculated for a section of the road based on 3 PPIs: IRI, rut depth and skid resistance. RSP is calculated for 6 PPIs, including different types of cracking, as well as rut depth. Any road section in question is assigned the lowest calculated RFP and RSP.

To be able to evaluate the residual life of pavement in regard to each performance indicator the performance curves are used. These curves should determine a distress level at any time during the pavement life. Thus, the performance curve provides rating for each distress type. Stampley, Miller, Smith, \& Scullion (1995) concluded that the basic shape of a pavement performance curve is sigmoidal ( $\mathrm{S}$-shaped).

PCA can be done by implementing different techniques, such as fuzzy logic and analytic hierarchy process (Sun \& Gu, 2011), machine learning algorithms (Marcelino, Lurdes Antunes, \& Fortunato, 2018), expert systems (Ismail, Ismail, \& Atiq, 2009), risk-informed approach (Ellingwood, 2005), soft computer approach (Singh, Sharma, Mishra, Wagle, \& Sarkar, 2018).

The development of pavement maintenance and management system requires modelling the pavement deterioration pattern using the data collected over years which is done using highway development and management tools like HDM-4. The tool attempts to build a regression model for the complex interaction between the pavement structure, traffic loading and the environmental conditions for predicting various kinds of distress developed in pavements over time (Singh \& Chopra, 2018). Since the distress levels and the weather conditions of the area surrounding the pavement network are highly correlated, these 
pavement distress models need to be calibrated with respect to a specific location before they can be used for inferencing.

Sivilevičius \& Vansauskas (2013) conducted a study on Lithuanian highways in regard to predicting rut depth, which seemed to be one of the main problems on Lithuanian roads. Ziliute et al. (2011) analysed research and data of asphalt pavement roughness and traffic intensity on streets of Vilnius while representing a heavy vehicle running model. They determined that heavy vehicle intensity could vary a lot depending on a street, up to a $23 \%$ increase per year, thus differing from highways.

The Urban Roadway Management System (URMS) was developed at the University of Texas at Austin (Sohail, Dossey, \& Hudson 1996). URMS provides small-to-medium sized cities with a simple, flexible, and userfriendly PMS. Implementation of such a system can save money for both the agency and the user, and improve not only the efficiency but also the effectiveness of decision making involved in managing pavements.

Kirbaş \& Karaşahin (2016) used three different modelling approaches: Deterministic Regression, MARS and Artificial Neural Network (ANN) to predict pavement deterioration for urban roads. They used a PCI index to be used in PAVER system - the most commonly used system for pavement management in urban roads. The ANN method was found to be the most appropriate model for predicting deterioration in urban roads. Nevertheless, the three models had prediction accuracy close to each other. Osorio (2015) reached a conclusion that the Urban Pavement Condition Index (UPCI) could be used in many countries if the Urban Road Management System was properly implemented. Three UPCI models were obtained for asphalt pavements with manual and automated data collection.

While evaluating pavement distress, it can be severe enough to require immediate action. This level of severity is called a threshold value. It represents the magnitude of a measurable pavement performance indicator that constitutes the minimum level of pavement structural soundness and functionality acceptable to the agency and users (Baladi et al., 2017). Threshold values can be used with PPIs or with any overall pavement condition index or rating. Table 1 presents a comparison of threshold values for some PPIs established in several reports used in the US to regulations used by the Lithuanian Road Administration. The presented threshold values do not suggest that an agency should wait until the pavement section reaches this value for any PPI. On the other hand, surpassing threshold values do not also require the agency to immediately close the road to public traffic. The threshold value is a management tool that helps planners and managers evaluate, assess, and make reasonable and potentially cost-effective decisions
Comparison

of Pavement Performance Models for Urban Road Management System 
regarding the conditions and serviceability of the pavement network (Baladi et al., 2017).

Table 1. Comparison of PPI threshold values

\begin{tabular}{|c|c|c|c|c|}
\hline PPI & $\begin{array}{l}\text { Gilbert Y. } \\
\text { Baladi et al., } \\
2017\end{array}$ & $\begin{array}{l}\text { AASHTO, } \\
2004\end{array}$ & $\begin{array}{c}\text { The Ohio Department } \\
\text { of Transportation, } \\
2006\end{array}$ & $\begin{array}{c}\text { Lietuvos } \\
\text { automobiliụ keliụ } \\
\text { direkcija, 2017, 2018 }\end{array}$ \\
\hline $\begin{array}{l}\text { IRI (primary and } \\
\text { sec-ondary roads) }\end{array}$ & $2.7 \mathrm{~m} / \mathrm{km}$ & $3.16 \mathrm{~m} / \mathrm{km}$ & & $4.5 \mathrm{~m} / \mathrm{km}$ \\
\hline Rut depth & $12.7 \mathrm{~mm}$ & $16.5 \mathrm{~mm}$ & $19.0 \mathrm{~mm}(>50 \%)$ & $20 \mathrm{~mm}$ \\
\hline Alligator cracking & $20 \%$ area & $35 \%$ area & & $>19 \mathrm{~mm}$ wide \\
\hline $\begin{array}{l}\text { Longitudinal } \\
\text { cracking }\end{array}$ & $\begin{array}{c}200 \mathrm{~m} / 100 \mathrm{~m} \\
\text { of lane }\end{array}$ & & $\begin{array}{c}>25 \mathrm{~mm} \text { wide, } 150 \mathrm{~m} / \\
0.1 \mathrm{~km}\end{array}$ & $>19 \mathrm{~mm}$ wide \\
\hline $\begin{array}{c}\text { Transverse } \\
\text { cracking }\end{array}$ & $\begin{array}{l}67 \mathrm{~m} / 100 \mathrm{~m} \\
\text { of lane }\end{array}$ & $\begin{array}{c}132.6 \mathrm{~m} / \mathrm{km} \\
\text { of lane }\end{array}$ & $\begin{array}{c}<0.9 \text { between cracks, } \\
>50 \%\end{array}$ & $>19 \mathrm{~mm}$ wide \\
\hline Block cracking & & & $\begin{array}{c}<0.9 \mathrm{~m} \times 0.9 \mathrm{~m},>50 \% \\
(>6 \text { per } \mathrm{km})\end{array}$ & \\
\hline Potholes & & & $>25 \mathrm{~mm}$ deep,$>0.84 \mathrm{~m} 2$ & $>$ layer thickness \\
\hline Ravelling & & & Rough or pitted $>50 \%$ & \\
\hline Bleeding & & & Black Surface $>30 \%$ & $\begin{array}{l}\text { Shiny Surface, tire } \\
\text { marks }\end{array}$ \\
\hline Patching & & & $>0.84 \mathrm{~m}^{2},>12$ per $\mathrm{km}$ & $\begin{array}{c}>30 \% \text { of patch is } \\
\text { defective }\end{array}$ \\
\hline
\end{tabular}

The brief summary of existing pavement deterioration models reveals that there are only a few pavement deterioration models for urban road networks (Shah et al., 2013). Therefore, in the present activity we focus on developing pavement deterioration models based on 15 urban road sections in the city of Vilnius, Lithuania (Table 1). The main objective of this study is to identify the parameters and to suggest the prediction model of asphalt pavement distress for management system of urban roads in Vilnius. The proposed methodology is tested on the studied road section, prioritising each section.

\section{Research scope and methodology}

The area of the city of Vilnius is $400.6 \mathrm{~km}^{2} .10 \%$ of this area consists of motorized urban roads. Of all the pavement types on Vilnius streets, asphalt is the most common one $(74 \%$ or $1049.8 \mathrm{~km})$ (Savivaldybes imonè "Vilniaus planas", 2009). This review paper deals only with 
distresses detected on the flexible pavement. This choice reflects the authors' aim to provide a state of the art useful to all urban municipalities in Lithuania.

\subsection{Urban roads}

To be able to correctly implement pavement performance models in this research, relevant data were to be collected from urban pavements in operation from Vilnius, the capital city of Lithuania. Pavement distresses as well as bearing capacity was the main focus of these measurements.

A total of 15 main urban roads of "B" category were analysed with a combined length of approx. $48 \mathrm{~km}$ with each road having 2 to 6 lanes in both directions. "B" category roads were chosen as they represented a typical high traffic volume road in Vilnius. "A" category roads were not considered as generally the driving speeds was higher than 80 $\mathrm{km} / \mathrm{h}$ which might not be a typical representative urban condition. "A" category roads also rarely accommodate public traffic routes, which in cities has a high impact on pavement distress formation. A list of studied urban road sections is presented in Table 2 .

Table 2. List of the studied urban road sections

\begin{tabular}{|c|c|c|c|c|c|c|}
\hline $\begin{array}{l}\text { Section } \\
\text { Number }\end{array}$ & Road Name & $\begin{array}{c}\text { Section } \\
\text { Length, km }\end{array}$ & $\begin{array}{l}\text { Measured } \\
\text { Lanes }\end{array}$ & AADT, vpd & $\begin{array}{c}\text { Heavy AADT, } \\
\%\end{array}$ & $\begin{array}{c}\text { Public } \\
\text { Transport, \% }\end{array}$ \\
\hline 1 & $\begin{array}{l}\text { Dariaus ir } \\
\text { Girèno }\end{array}$ & 3.16 & 4 & 20908 & 14.51 & 0.80 \\
\hline 2 & Dunojaus & 0.57 & 4 & 18964 & 23.24 & 0.00 \\
\hline 3 & Geležinkelio & 0.90 & 2 & 20930 & 25.49 & 6.97 \\
\hline 4 & Liepkalnio & 6.20 & 4 & 20075 & 29.78 & 1.12 \\
\hline 5 & Nemenčinès & 10.04 & 4 & 17417 & 16.64 & 0.23 \\
\hline 6 & Olandy & 1.58 & 4 & 21701 & 20.31 & 0.75 \\
\hline 7 & Ozo & 2.14 & 6 & 37493 & 16.56 & 0.86 \\
\hline 8 & Pilaitès & 4.35 & 4 & 27771 & 13.11 & 1.08 \\
\hline 9 & Savanorių & 5.71 & 6 & 36032 & 9.47 & 1.78 \\
\hline 10 & Šeimyniškių & 1.13 & 4 & 18091 & 18.52 & 3.33 \\
\hline 11 & Stepono Batoro & 7.02 & 4 & 28009 & 17.78 & 0.71 \\
\hline 12 & T. Narbuto & 2.71 & 4 & 27970 & 16.38 & 3.11 \\
\hline 13 & Vilkpèdès & 1.19 & 2 & 17042 & 3.70 & 0.82 \\
\hline 14 & Žemaitès & 0.76 & 3 & 26309 & 2.11 & 0.79 \\
\hline 15 & Žirmūnų & 3.25 & 4 & 18535 & 10.41 & 3.30 \\
\hline
\end{tabular}




\subsection{Measurement methods}

The aim of this study is to provide Vilnius city municipality as well as other municipalities with the information on their pavement condition with tools easily available for them. Therefore, no destructive tests were carried out on Vilnius streets. Non-destructive tests (NDTs) are important for the structural evaluation of pavements.

The NDT measurements on urban roads of Vilnius were conducted with the help of two research devices. Mobile Road Research Laboratory RST 28 produced by Ramböll RST was used for surface technical parameter and distress measurements.

RST 28 measurements were carried out by the Road and Transport Research Institute during summer of 2017 from 8 June to 25 July. A total of 17810 measurements were taken on 15 urban roads with a total length of $178.1 \mathrm{~km}$. Measurements were taken at the intervals of 10 meters. Speed at which the measurement vehicle was traveling varies from $17.7 \mathrm{~km} / \mathrm{h}$ to $62.2 \mathrm{~km} / \mathrm{h}$, depending on a road. For all roads, RST measurements were carried out for the 1st rightmost lane in each direction not counting the dedicated public transport lane. If the road had 2nd lane in any direction, it was measured as well. For 3 roads (numbers 7, 8 and 9) the dedicated transport lane was also measured. The following relevant pavement technical parameters were recorded:

- international roughness index (IRI) in $\mathrm{m} / \mathrm{km}$ along the left and right wheel path, as well as the mean value;

- rut depth in $\mathrm{mm}$ along the left and right wheel path, as well as the mean value;

- cracks (transverse, longitudinal, alligator) in \% of lane area;

- surface defects (patches, pot holes) in \% of lane area.

To determine the bearing capacity of the same road sections the second research device - falling weight deflectometer (FWD) - was used. The impulse loads applied by FWD model a typical tire of a heavy vehicle moving at a velocity of approximately $60 \mathrm{~km} / \mathrm{h}$ (Matini, Tabatabaee, \& Abbasghorbani, 2018). FWD captures dynamic deflections of the road pavement. During testing the load of $50 \mathrm{kN}$ was applied to the road pavement. Deflections are recorded by 9 sensors called geophones. Each geophone is positioned at a different distance from the centre of the loading plate $(0 \mathrm{~mm}, 200 \mathrm{~mm}, 300 \mathrm{~mm}, 450 \mathrm{~mm}, 600 \mathrm{~mm}, 900 \mathrm{~mm}$, $1200 \mathrm{~mm}, 1500 \mathrm{~mm}, 1800 \mathrm{~mm}$ ).

FWD measurements were carried out by the Road and Transport Research Institute during spring-summer of 2017 from 29 May to 20 June. A total of 664 measurements were taken on 15 urban roads with a total length of $99.6 \mathrm{~km}$. Three load drops were made during each measurement. The $3 \mathrm{rd}$ drop is considered in the research. 
Measurements were taken at the intervals of approx. 150 meters. For all roads, FWD measurements were carried out for the 1st rightmost lane in each direction not counting the dedicated public transport lane.

During deflection measurement, on some of the roads pavement structure was probed, investigating asphalt layer thickness as well base and sub-base layer thickness and material type. In addition, the asphalt layer temperature at a half-layer depth was recorded. It was later used for normalizing deflections to a reference temperature of $20^{\circ} \mathrm{C}$. From the deflections, Surface Curvature Index SCI300 was derived, which was chosen to represent bearing capacity in this paper.

\subsection{Analysis methods}

To determine the urban pavement condition in Vilnius, two methodologies were used. The first one is based on COST (2008) Action 354 "Performance Indicators for Road Pavements". This methodology was derived involving 23 European countries and the FHWA/USA. Based on a comprehensive investigation that included an extensive literature research and the analysis of questionnaires sent to road operators in the participating countries, a set of performance indicators was developed (COST, 2008). The report defines a performance indicator as a superior term of a technical road pavement parameter, which can define its condition. COST Action 354 distinguishes four levels of performance indicators.

1. Technical parameter (TP) - a physical characteristic of the road pavement condition, derived from various measurements, or collected by other forms of investigation (e.g., rut depth, friction value, etc.).

2. Performance index (PI) - an assessed technical parameter of the road pavement, dimensionless number or letter on a scale that evaluates the technical parameter involved (e.g., rutting index, skid resistance index, etc.) on a 0 to 5 scale, 0 being a very good condition and 5 - a very poor one.

3. Combined performance indicator (CPI) - a dimensional or dimensionless number related to two or more different characteristics of the road pavement, which indicate the condition of all the characteristics involved.

4. Global performance indicator (GPI) - a mathematical combination of single and/or combined indicators, which describe the pavement condition concerning different aspects like safety, structure, riding comfort and environment.

The second methodology used in this research is the one described in "Guidelines for the Assessment of the State of Road Surfaces of National
Comparison of Pavement Performance Models for Urban Road Management System 
Importance" (Valstybinès reikšmès kelių dangos būklès vertinimo tvarkos aprašas), which was derived from COST Action 354 by the Lithuanian Road Administration (LRA) in 2018. This methodology uses similar four levels of performance indicators (Lietuvos automobilių keliu direkcija, 2018).

Valid for both methods, each higher level of performance indicator is derived from pervious. PI is calculated from TP via transfer functions, which are essentially an equation to convert single TP with dimension to a single dimensionless PI. Transfer functions and TPs used to calculate PIs are presented in Table 3.

Table 3. Transfer functions and TPs used to calculate PIs

\begin{tabular}{|c|c|c|c|}
\hline \multirow{2}{*}{$P I$} & \multirow{2}{*}{ TP used } & \multicolumn{2}{|c|}{ Transfer function* } \\
\hline & & COST & LRA \\
\hline $\begin{array}{l}\text { Longitudinal Evenness, } \\
\qquad P I_{E}\end{array}$ & $I R I, \mathrm{~m} / \mathrm{km}$ & $0.816 \cdot I R I$ & $2 \cdot|R|-5.02$ \\
\hline $\begin{array}{c}\text { Transverse Evenness, } \\
\qquad P I_{R}\end{array}$ & Rut depth, RD & $\begin{array}{c}-0.0015 \cdot R D^{2}+ \\
0.2291 \cdot R D\end{array}$ & $0.2 \cdot R D$ \\
\hline Bearing Capacity, $P I_{B}$ & $\mathrm{SCl} 300, \mu \mathrm{m}$ & SCI300/129 & - \\
\hline Cracking, PICR & Cracking rate $(C R), \%$ & $0.1333 \cdot C R$ & $\begin{array}{c}\text { if } C R \geq 8.73 \% \text { then } 5 \\
\text { if } C R<8.73 \% \text { then } \\
-0.0669 \cdot C R^{2}+1.1379 \cdot C R\end{array}$ \\
\hline Surface defects, PISD & $\begin{array}{l}\text { Surface defect rate } \\
\text { (SD), \% }\end{array}$ & $0.1333 \cdot S D$ & $\begin{array}{c}\text { if } S D \geq 6.9 \% \text { then } 5 \\
\text { if } S D<6.9 \% \text { then } \\
-0.0942 \cdot S D^{2}+1.3412 \cdot S D\end{array}$ \\
\hline Skid resistance, $P I_{F}$ & $\begin{array}{l}\text { Longitudinal friction } \\
\text { coefficient, LFC } \\
(50 \mathrm{~km} / \mathrm{h})\end{array}$ & $-13.875 \cdot L F C+9.338$ & - \\
\hline
\end{tabular}

Note: * if the calculated $P I$ is less than 0 , then $P I=0$, if $P I$ is more then 5 , then $P I=5$.

The combination of single PIs into CPIs is based on the advanced maximum criteria. It takes into account the maximum weighted PI value affected by biased values of other weighted PIs. By using this method, it is possible to combine different indices under different preconditions. This method was selected in order to ensure that the final result of the CPI was strongly influenced by the maximum weighted PI (COST, 2008). CPI is calculated from 1-5 PIs involving weight factors (Eq. 1). Each different CPI consists of a different set of PIs and they vary depending on a method. The set of PIs for each CPI, as well as weight factors applied to each PI are presented in Table 4. It should be noted that Safety CPI 
requires Skid Resistance PI, which is derived from Sideways Friction Coefficient (SFC) or Longitudinal Friction Coefficient (LFC). None of these parameters were measured in this research. In order to still be able to calculate Safety CPI, LFC value of 0.45 on all urban roads was used. Therefore, the weight factor of friction PI was lowered to 0.5.

$$
\begin{aligned}
& C P I_{i}=I_{1}+\frac{p}{100} \cdot \overline{I_{2}, I_{3}, \ldots, I_{n}} ; \\
& I_{1} \geq I_{2} \geq \ldots \geq I_{n} ; \\
& I_{n}=W_{n} P I_{n},
\end{aligned}
$$

where CPI - the combined performance indicator ( $\max 5$ ); $p$ - an influence factor (chosen 20\%); $P I_{n}$ - performance indices; $W_{n}$ - weight factors.

Table 4. Weight factors used in the research for calculating different CPIs

\begin{tabular}{cccccccc}
\hline CPI & Methodology & $\boldsymbol{P I}_{\mathrm{B}}$ & $\boldsymbol{P I _ { C R }}$ & $\boldsymbol{P I _ { R }}$ & $\boldsymbol{P I}_{\mathrm{E}}$ & $\boldsymbol{P I}_{\mathrm{SD}}$ & $\boldsymbol{P I}_{\mathrm{F}}$ \\
\hline \multirow{2}{*}{ Structural } & COST & 1 & 0.9 & 0.5 & 0.6 & - & - \\
& LRA & - & - & 0.556 & 1 & 0.667 & - \\
\multirow{3}{*}{ Comfort } & COST & - & 0.5 & 0.7 & 1 & 0.6 & - \\
& LRA & - & 0.5 & 0.7 & 1 & 0.6 & - \\
\multirow{2}{*}{ Safety } & COST & - & - & 0.9 & - & 0.6 & 0.5 \\
& LRA & - & - & 1 & - & 0.667 & - \\
\hline
\end{tabular}

The conjunction of combined performance indices (CPIs) into a general performance index (GPI) is based on the advanced maximum criteria already presented in the context of calculation of CPIs. It takes into account the maximum weighted CPI value affected by biased values of other weighted CPIs. By using this method, it is possible to combine different indices under different preconditions (COST, 2008). GPI is calculated from at least these 3 CPIs: structural, comfort and safety. The calculation is also done involving weight factors (Eq. 4). GPI was calculated for both methodologies. The weight factors determined for local roads were used for GPI calculation. The weight factors applied to calculate GPI using both methodologies are as follows: $W_{\text {comfort }}=0.65$; $W_{\text {safety }}=1.0 ; W_{\text {structural }}=1.0$.

$$
\begin{aligned}
& G P I=I_{1}+\frac{p}{100} \cdot \overline{I_{2}, I_{3}, \ldots, I_{n}} ; \\
& I_{1} \geq I_{2} \geq \ldots \geq I_{n} \\
& I_{n}=W_{n} C P I_{n} .
\end{aligned}
$$

Comparison of Pavement Performance Models for Urban Road Management System 


\section{Results and discussion}

\subsection{Severity of distresses of urban road pavement}

In order to assess urban road pavement distress severity IRI, rut depth, crack area and surface area were measured and calculated. The mean IRI throughout all 15 urban roads was $3.62 \mathrm{~m} / \mathrm{km}$ ranging from $0.38 \mathrm{~m} / \mathrm{km}$ to $30.93 \mathrm{~m} / \mathrm{km}$ (Figure $1 \mathrm{a}$ ). It was found that half of pavements had IRI varying from $1.89 \mathrm{~m} / \mathrm{km}$ to $4.42 \mathrm{~m} / \mathrm{km}$. $25 \%$ of pavements had IRI above $4.42 \mathrm{~m} / \mathrm{km}$. Comparing to a $2.7 \mathrm{~m} / \mathrm{km}$ limit used in Baladi et al. (2017), 52.7\% of measurements were above the specified threshold value; comparing to a $3.16 \mathrm{~m} / \mathrm{km}$ limit used in AASHTO (2004), 42.9\% of measurements were above the specified threshold value; comparing to a $4.5 \mathrm{~m} / \mathrm{km}$ limit used in Lietuvos automobilių keliu direkcija prie Susisiekimo ministerijos (2017), 24.1\% of measurements were above the specified threshold value. Roads No. 1 , 2, 3, 6 and 10 had mean IRI more than $5.0 \mathrm{~m} / \mathrm{km}$.

The mean rut depth throughout all 15 urban roads was $9.4 \mathrm{~mm}$ ranging from $0.5 \mathrm{~mm}$ to $51.1 \mathrm{~mm}$ (Figure $1 \mathrm{~b}$ ). It was found that half of pavements had rut depth varying from $4.5 \mathrm{~mm}$ to $12.8 \mathrm{~mm}$. $25 \%$ of pavements had rut depth above $12.8 \mathrm{~mm}$. Comparing to a $12.7 \mathrm{~mm}$ limit used in Baladi et al. (2017), 25.3\% of measurements were above the specified threshold value; comparing to a $16.5 \mathrm{~mm}$ limit used in AASHTO (2004), 14.8\% of measurements were above the specified threshold value; comparing to a $19 \mathrm{~mm}$ limit used in the Ohio Department of Transportation (2006), 9.9\% of measurements were above the specified threshold value; comparing to a $20 \mathrm{~mm}$ limit used in Lietuvos automobilių kelių direkcija prie Susisiekimo ministerijos (2017), 8.3\% of measurements were above the specified threshold value.

The mean defected area (crack area + area of surface defects) throughout all 15 urban roads was $7.1 \%$ ranging from $0 \%$ to $96.9 \%$ at some $10 \mathrm{~m}$ long stretches (Figure 1c). It was found that more than a half $(51.4 \%)$ pavement had no defects at all, $33.2 \%$ of pavements had at least $5 \%$ defected $10 \mathrm{~m}$ long stretches, $20.1 \%$ of pavements had at least $10 \%$ defected $10 \mathrm{~m}$ long stretches, $2.4 \%$ of pavements had at least $50 \%$ defected $10 \mathrm{~m}$ long stretches. It is hard to compare cracked and defected area to any threshold value given in Table 1 as the dimensions and individual distress grouping is different than the used measurement devices are able to provide.

The mean deflection obtained from FWD throughout all 15 urban roads was $302.1 \mu \mathrm{m}$ ranging from $129.0 \mu \mathrm{m}$ to $717.0 \mu \mathrm{m}$ (Figure $1 \mathrm{~d}$ ). It 
was found that half of pavements had deflections varying from $238.0 \mu \mathrm{m}$ to $346.0 \mu \mathrm{m} .25 \%$ of pavements had deflections above $346 \mu \mathrm{m}$.

\subsection{Combined and global performance indicators}

Combined performance indicators (CPIs) for structural, comfort and safety components were calculated for each of 15 urban roads in Vilnius based on the Lithuanian Road Administration's "Guidelines for the Assessment of the State of Road Surfaces of National Importance" (Lietuvos automobilių kelių direkcija, 2018) (Figure 2) as well as COST Action 354 (2008) (Figure 3). The global performance indicator was also derived from the analysis for both methodologies.

a)

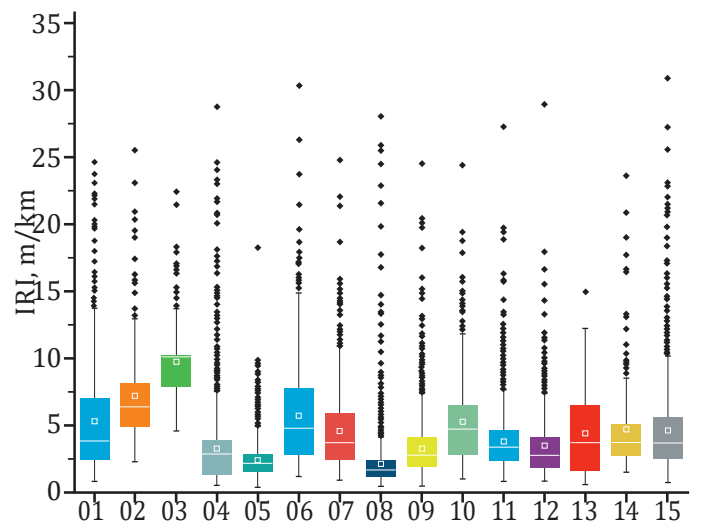

b)

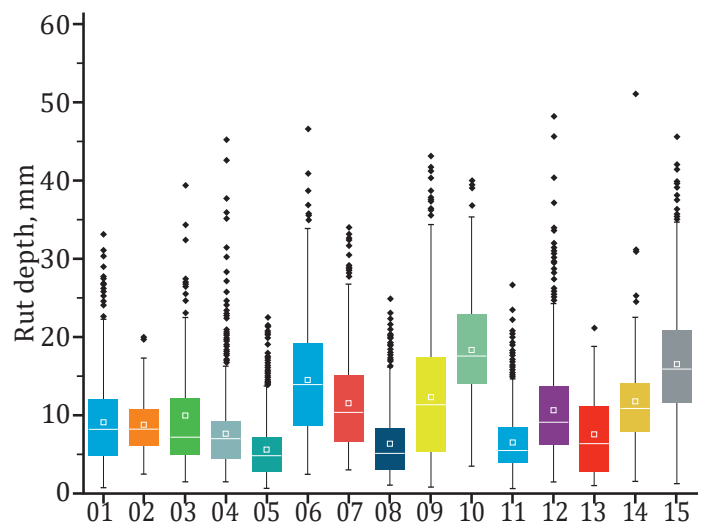

d)

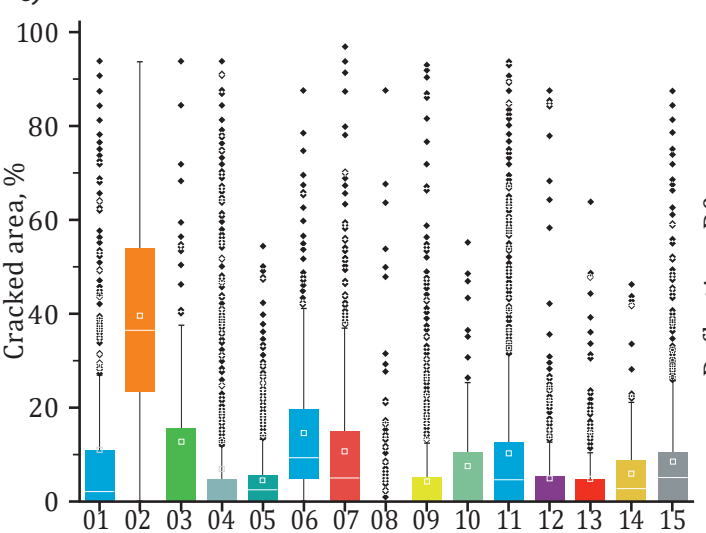

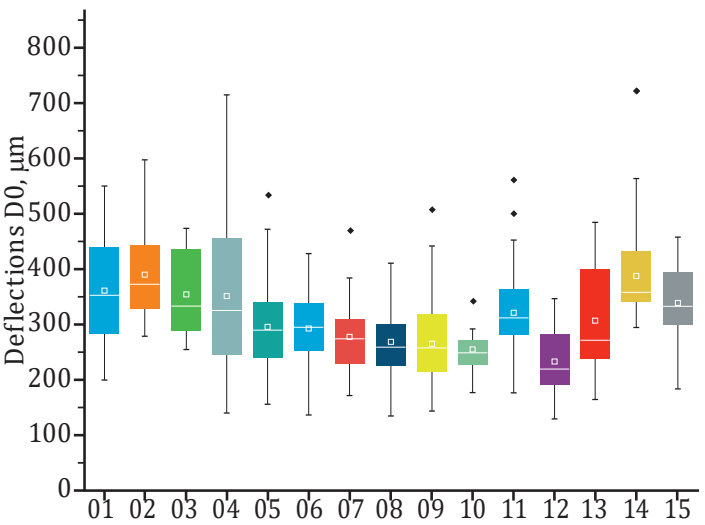

Figure 1. Pavement distress and performance measurement results: a) IRI;

b) rut depth; c) defected area; d) FWD deflections 
The mean value of GPI based on LRA methodology for all the road sections was 3.12 ranging from 1.32 to 5.0. None of the roads had a "very good" condition, 3 had "good", 4 had "satisfactory", 5 had "bad" and 3 had "very bad" conditions. What is expected, the roads with a high heavy traffic percentage generally have a lower condition index. In almost half the roads ( 7 total), the safety CPI was found to be the most influencing, even though its mean value across all pavements was lower than structural or comfort CPIs (2.28 to 2.61 and 2.65, respectively). The safety CPI had also the lowest standard deviation compared to structural or comfort CPIs ( 0.75 to 1.21 and 1.15 , respectively). This means that the safety index does not vary that much on urban roads and it can become crucial only when other CPIs are lower.

The mean value of GPI based on the COST methodology for all the road sections was 2.88 ranging from 1.97 to 4.16. Most of the road sections (10) had a "satisfactory" condition, none of the sections had a "very good" condition, 1 had "good", 3 had "bad" and 1 had "very bad" conditions. The structural and safety CPIs were very similar for all road sections with a mean values of 2.37 and 2.42 , respectively. The comfort CPI was generally higher than the other CPIs (mean value of 3.22), but because its weight factor was the smallest, it did not influence GPI to a large extent. As a consequence, on some road sections the GPI was lower

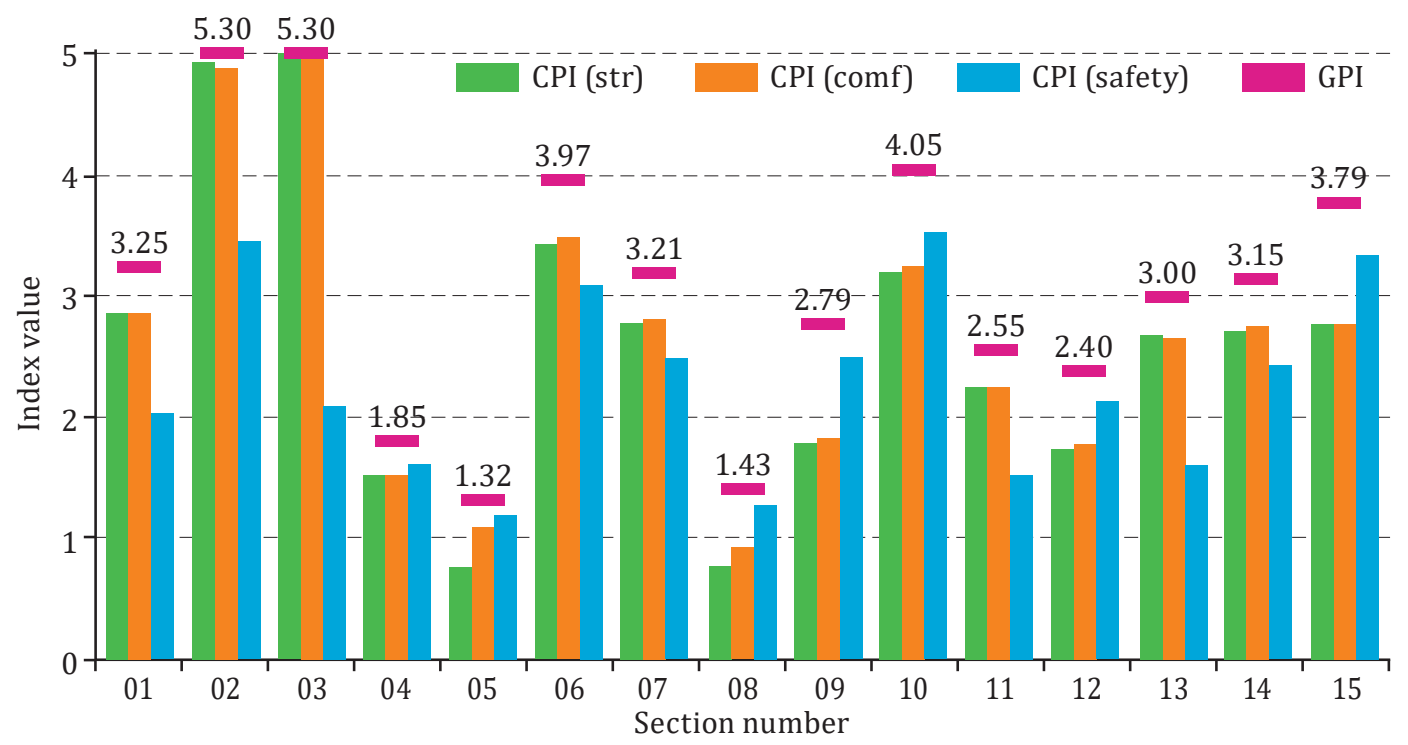

Figure 2. Comparison of the combined performance indicators (structural, comfort and safety) as well as global performance indicator (based on the methodology by the Lithuanian Road Administration) 
than the comfort CPI, when in case of LRA methodology, GPI was always higher than any CPI.

Comparison of structural CPI from two different methods - LRA and COST - shows us that the both values are not very different, but generally the LRA value is higher (10 roads out of 15 ). On several roads (No. 2, 3, 6, 10) the LRA value is much higher. This is the evidence of a different set of PIs used in the CPI calculation. The COST method uses bearing capacity as one of the components for structural CPI, while LRA relies on pavement surface properties. In this regard, the COST method is more reliable. Comparing comfort CPI from two different methods LRA and COST -, results are very similar values for both methods. The vast majority of roads (14 roads out of 15 ) exhibited a higher comfort CPI calculated via the COST method. The weight factors for calculating CPI from PI are identical; it means that the difference comes from calculating the PIs. Comparison of the safety CPI shows no significant difference in results. The average value for all the roads for the COST and LRA methodologies was 2.42 and 2.28, respectively. It is possible that the results for the COST methodology would be more accurate having reliable surface friction data, though the similarity in results indicates a proper weight coefficient choice.
Comparison of Pavement Performance Models for Urban Road Management System

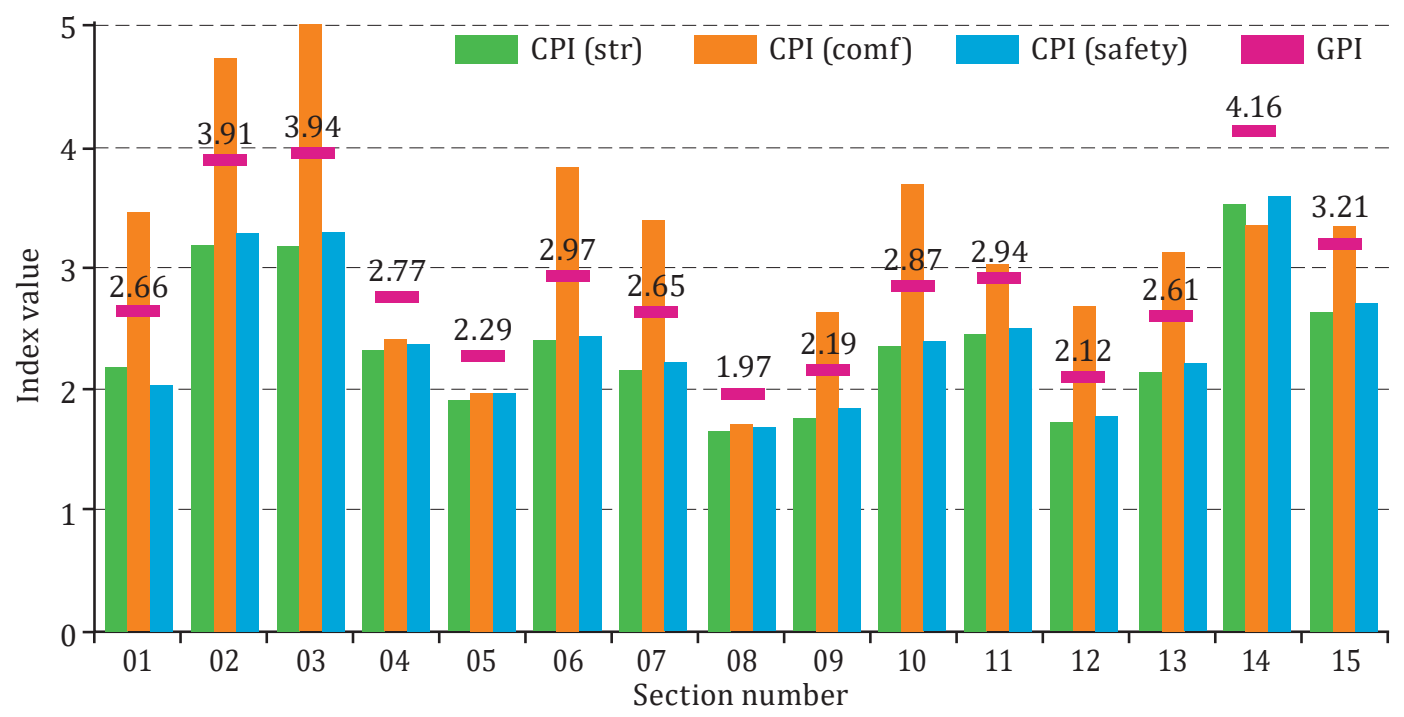

Figure 3. Comparison of the combined performance indicators (structural, comfort and safety) as well as global performance indicator (based on the methodology by COST 354) 


\section{Conclusions}

Pavement condition assessment is well experienced in rural rods, though there is a lack of experience in an urban road network. There is no general method for the determination of an urban road pavement condition index. Lack of knowledge regarding the assessment of the urban road network pavement condition indicates the need for an extensive research and data collection.

Essential part of pavement condition assessment is the determination of the damaged area and how it can affect pavement performance in future. These parameters are based on the established threshold values. For urban road networks such values need to be selected individually with regard to available $R \& R$ funds, though they cannot exceed safety threshold values.

Upon evaluating the pavement condition on 15 urban roads of category $\mathrm{B}$ in the city of Vilnius, a mean IRI for those pavements was $3.62 \mathrm{~m} / \mathrm{km}$ and a half of pavements had IRI in the interval from $1.89 \mathrm{~m} / \mathrm{km}$ to $4.42 \mathrm{~m} / \mathrm{km}$. Mean rut depth was $9.4 \mathrm{~mm}$ and a half of pavements had rut depth in the interval from $4.5 \mathrm{~mm}$ to $12.8 \mathrm{~mm}$. The mean defected area was $7.1 \%$ ranging from $0 \%$ to $96.9 \%$ at some $10 \mathrm{~m}$ long stretches, while half (51.4\%) pavement had no defects at all, $15.4 \%$ had less than $5 \%$ defects and $33.2 \%$ of pavements had at least $5 \%$ defects.

Bearing capacity of all road sections was evaluated via pavement deflections measured by FWD under $50 \mathrm{kN}$. The mean deflection, normalized to $20{ }^{\circ} \mathrm{C}$, for all sections was $302.1 \mu \mathrm{m}$ ranging from $129.0 \mu \mathrm{m}$ to $717.0 \mu \mathrm{m}$. This variation is high even though the urban road category was the same for all sections.

Both the analysed and compared methods (LRA and COST) offer the same combined performance indices (CPI): structural, comfort and safety. However, the set of single performance indices (PI) involved in each CPI calculation differs depending on the methodology, i.e., the structural CPI for road sections No. 2 and 3 was $1.72-1.80 \mathrm{~m}$ higher when derived from the LRA methodology rather than the COST. In this regard, the COST method is more reliable as it uses bearing capacity as one of the components and the LRA method relies only on the pavement surface condition.

The COST method showed a more consistent condition for the evaluated sections, as 10 out of 15 sections fell under the "satisfactory" condition. The LRA method placed the section pavement condition ranging from "very bad" to "good" without any distinguishable majority.

Further research on the proposed methodology calibration is required. Expanding the range of the studied urban roads, including 
less (C and D) and more significant (A) road categories as well as performing friction measurements on these roads should help make the pavement condition assessment methods more precise. Next step could be calibrating the weight factors of each PI and CPI by comparing the study results on the same road sections several operating years later. These steps should bring closer the implementation of urban PMS in the Lithuanian cities.

\section{REFERENCES}

AASHTO. (1993). AASHTO Guide for Design of Pavement Structures.

AASHTO. (2004). Chapter 6: HMA Rehabilitation of Existing Pavement. In Guide for Mechanistic-Empirical Design of New and Rehabilitated Pavement Structures, Part 3.

Adlinge, S. S., \& Gupta, A. K. (2013). Pavement Deterioration and Its Causes. Journal of Mechanical \& Civil Engineering, 9-15.

Baladi, G. Y., Dawson, T., Musunuru, G., Prohaska, M., \& Thomas, K. (2017). Pavement Performance Measures and Forecasting and the Effects of Maintenance and Rehabilitation Strategy on Treatment Effectiveness (Revised). Publication No. FHWA-HRT-17-095. In Distribution (Issue September). https://www.fhwa.dot.gov/publications/research/ infrastructure/pavements/ltpp/17095/17095.pdf

COST. (2008). COST Action 354. Performance Indicators for Road Pavements. Final Report. (Issue July).

Ellingwood, B. R. (2005). Risk-informed condition assessment of civil infrastructure: state of practice and research issues. Structure and Infrastructure Engineering, 1(1), 7-18. https://doi.org/10.1080/15732470412331289341

Gavilán, M., Balcones, D., Marcos, O., Llorca, D. F., Sotelo, M. A., Parra, I., Ocaña, M., Aliseda, P., Yarza, P., \& Amírola, A. (2011). Adaptive road crack detection system by pavement classification. Sensors, 11(10), 9628-9657. https://doi.org/10.3390/s111009628

Haas, R., Hudson, W. R., \& Falls, L. C. (2015). Pavement Asset Management. https://doi.org/10.1002/9781119038849

Huang, Y. H. (2004). Pavement analysis and design (2nd edition).

Huidrom, L., Das, L. K., \& Sud, S. K. (2013). Method for Automated Assessment of Potholes, Cracks and Patches From Road Surface Video Clips. Procedia Social and Behavioral Sciences, 104, 312-321. https://doi.org/10.1016/j.sbspro.2013.11.124

Ismail, N., Ismail, A., \& Atiq, R. (2009). An Overview of Expert Systems in Pavement Management. European Journal of Scientific Research, 30(1), 99-111.

Kirbaş, U., \& Karaşahin, M. (2016). Performance Models for Hot Mix Asphalt Pavements in Urban Roads. Construction and Building Materials, 116, 281-288. https://doi.org/10.1016/j.conbuildmat.2016.04.118
Comparison

of Pavement

Performance

Models for Urban

Road Management

System 
Koch, C., \& Brilakis, I. (2011). Pothole Detection in Asphalt Pavement Images. Advanced Engineering Informatics, 25(3), 507-515. https://doi.org/10.1016/j.aei.2011.01.002

Lietuvos automobilių kelių direkcija. (2017). Valstybinès reikšmès kelių pažaidų matavimo ir nustatymo tvarkos aprašas. 6, 25.

Lietuvos automobilių kelių direkcija. (2018). Valstybinès reikšmės kelių dangos būklès vertinimo tvarkos aprašas. 16(V).

Lovas, T., Kertész, I., Fi, I., \& Barsi, A. (2008). Photogrammetric pavement detection system. In I. L. Al-Qadi, T. Scarpas, A. Loizos (Eds.), Pavement Cracking: Mechanisms, Modeling, Detection, Testing and Case Histories (pp. 873-880, Figure 2). https://doi.org/10.1201/9780203882191.ch85

Marcelino, P., Lurdes Antunes, M. de, \& Fortunato, E. (2018). Comprehensive performance indicators for road pavement condition assessment. Structure and Infrastructure Engineering, 14(11), 1433-1445. https://doi.org/10.1080/15732479.2018.1446179

Matini, N., Tabatabaee, N., \& Abbasghorbani, M. (2018). Protocol for FWD Data Collection at Network-Level Pavement Management in Iran. Transportation Research Record, 2672(40), 68-77. https://doi.org/10.1177/0361198118758392

Osorio, A. (2015). Development of Performance Models and Maintenance Standards of Urban Pavements for Network Management (Doctoral thesis). University of Waterloo.

Pinkofsky, L., \& Jansen, D. (2018). Structural pavement assessment in Germany. Frontiers of Structural and Civil Engineering, 12(2), 183-191. https://doi.org/10.1007/s11709-017-0412-z

Ragnoli, A., De Blasiis, M. R., Di Benedetto, A., Blasiis, M. R. De, \& Benedetto, A. Di. (2018). Pavement Distress Detection Methods: A Review. Infrastructures, 3(4), 58. https://doi.org/10.3390/infrastructures3040058

Savivaldybès įmonè "Vilniaus planas". (2009). Vilniaus miesto savivaldybès teritorijos bendrasis planas iki 2015 metų.

Shah, Y. U., Jain, S. S., Tiwari, D., \& Jain, M. K. (2013). Development of Overall Pavement Condition Index for Urban Road Network. Procedia - Social and Behavioral Sciences, 104, 332-341. https://doi.org/10.1016/j.sbspro.2013.11.126

Singh, A. P., Sharma, A., Mishra, R., Wagle, M., \& Sarkar, A. K. (2018). Pavement condition assessment using soft computing techniques. International Journal of Pavement Research and Technology, 11(6), 564-581. https://doi.org/10.1016/j.ijprt.2017.12.006

Singh, A., \& Chopra, T. (2018). Development of Pavement Maintenance Management System for the Urban Road Netwrok By Calibrating the HDM-4 Distress Models. In International Conference on Pavements and Computational Approaches (ICOPAC) (pp. 239-241).

Sivilevičius, H., \& Vansauskas, V. (2013). Research and evaluation of ruts in the asphalt pavement on Lithuanian highways. Journal of Civil Engineering and Management, 19(5), 609-621.

https://doi.org/10.3846/13923730.2013.817481 
Sohail, F., Dossey, T., \& Hudson, W. R. (1996). Implementation of the Urban Roadway Management System. Report.

Stampley, B. E., Miller, B., Smith, R. E., \& Scullion, T. (1995). Pavement management information system concepts, equations, and analysis models. TX-96/1989-1. Report No. TX-96/1989-1.

Sun, L., \& Gu, W. (2011). Pavement condition assessment using fuzzy logic theory and analytic hierarchy process. Journal of Transportation Engineering, 137(9), 648-655. https://doi.org/10.1061/(ASCE)TE.1943-5436.0000239

The Ohio Department of Transportation. (2006). Pavement condition rating system.

TKTI. (1994). Asfaltbetonio dangų defektų nustatymo metodika.

Wang, T., Gopalakrishnan, K., Smadi, O., \& Somani, A. K. (2018). Automated shape-based pavement crack detection approach. Transport, 33(3), 598-608. https://doi.org/10.3846/transport.2018.1559

Xu, B., \& Huang, Y. (2005). Automatic inspection of pavement cracking distress. Applications of Digital Image Processing XXVIII, 5909(22), 590901. https://doi.org/10.1117/12.613770

Ziliute, L., Laurinavicius, A., \& Kleiziene, R. (2011). Investigation and analysis of heavyweight traffic running loads in streets of Vilnius city. In 8th International Conference on Environmental Engineering (pp. 1261-1267).
Comparison

of Pavement Performance Models for Urban Road Management System 